\title{
Effect of Soil Chemical and Physical Properties on Cd Mobility Studied by Soil Thin-Layer Chromatography
}

\author{
S.S. AL-OUD*, M.H EL-SAEID and M. E. A. NADEEM \\ Soil Sciences Department, College of Food \& Agricultural Sciences, \\ King Saud University, P.O. Box 2460, Riyadh 11451, Kingdom of Saudi Arabia.
}

http://dx.doi.org/10.12944/CWE.9.3.02

(Received: November 21, 2014; Accepted: December 09, 2014)

\begin{abstract}
Heavy metals contamination threat to the environment is a big concern. Predicting the movement of heavy metals such as Cd in soil is an important goal. In this study the effect of soil chemical and physical properties on $\mathrm{Cd}$ mobility were done using a thin layer chromatography (Soil TLC). The soils used in this research have a wide range of organic matter $(2.1-29 \mathrm{~g} / \mathrm{kg}), \mathrm{pH}$ value (4.9-8.8), CEC (4.1-99 cmol/kg), bases saturation, iron and aluminum oxides to examines its effect on $\mathrm{Cd}$ mobility. The (Rf) values obtained from soil thin layer chromatography ranged from 0.25 to 0.95 and it showed that Cd was slightly mobile in $64 \%$, moderately mobile in $29 \%$ and very mobile in $7 \%$ of the soils. The Rf indicates that Cd mobility would decrease with increasing amounts of iron oxide fractions; silt \% and exchangeable $\mathrm{Mg}^{2+}$ in the soils. Rcd values increased with increasing amounts of the iron oxide fractions (Feo, Fep, and Fed); silt \% and exchangeable $\mathrm{Mg}^{2+}$ in the soils. Finally, both Rcd and Rf factors showed Cd mobility to be higher in those soils with a high percentage of sand.
\end{abstract}

Key words: Cadmium, mobility, Soil, TLC, Heavy metal.

\section{INTRODUCION}

Heavy metal contamination is of concern due to release of metals in the environment by numerous factors like the industrial activities and in agricultural soils due to use of fertilizers, pesticides, fungicides and herbicides (Roth, et. al., 2012). Cadmium (Cd) in one of the heavy metals which is most mobile and bioavailable and is of high concern for its ecotoxicity. This has been demonstrated in various studies showing impact of $\mathrm{Cd}$ contamination on soil, groundwater, ecosystems and agriculture (Moradi et al., 2005; Keller et al., 2002; Van der Grift and Griffioen,2008). Cd sorption to soil phases mainly depends on soil properties like the $\mathrm{pH}$, soil organic matter and clay content (Streck and Richter, 1997; Deurer and Bottcher, 2007). Cd partitions between solid phases and soil solution affect the sorption and desorption processes which in turn affect the $\mathrm{Cd}$ toxicity, mobility, bioavailability and reactivity in environment.

Soil constituents along with the metal hydroxides are indicated to be participating in the sorption and desorption of $\mathrm{Cd}$ in soil(Krishnamurti and Naidu, 2003; Calace et al., 2009). Several important factors controlling the distribution of $\mathrm{Cd}$ between soil and solutes have been identified. The concentration of competing cations such as $\mathrm{Ca}$ or other heavy metals, $\mathrm{pH}$ and organic matter content significantly affect the $\mathrm{Cd}$ sorption equilibrium (Vega, et. al.,2010). Minimizing the threat of soil and groundwater pollution by accurately predicting the movement and cycling of hazardous contaminants is an ultimate goal. It has been suggested that the soil is the ultimate receptacle of most solid and liquid wastes (Shaheen, 2009). 
After studying the movement of some trace elements including $\mathrm{Cd}$ in 11 soils, it was reported that the soil texture, surface area, percentage of iron oxides, and $\mathrm{pH}$ provide the most useful information for estimating an element's migration (Seguraet al., 2006). It was reported that when the $\mathrm{pH}$ value dropped below 6, the mobility of $\mathrm{Cd}$ increases as compared with a higher $\mathrm{pH}$ value. Moreover, they added that the availability of heavy metals is lower in natural loamy soils than in sandy acidic soils due to precipitation of carbonates and phosphates in the former soil type(Scokat et al., 1983).

Metals may occur in the soil solution in different forms, each having a different mobility and toxicity. Hydrolysis species of $\mathrm{Cd}$ do not contribute to total $\mathrm{Cd}$ in acidic soils (Lindsay, 1979). Studies done on the chemistry of metals in forest soils of South Sweden have shown a strong correlation between soil solution $\mathrm{pH}$ and total Cd (Berggren,1992). Cadmium was shown to be fairly mobile in soils of $\mathrm{pH} 4.6$ to 6.6 and moderately mobile in those between 6.7-7.8 pH units(Fuller, 1977). The mobility of $\mathrm{Cd}$ in various natural soils by soil thin-layer chromatography was studies and was found that, the ratio of distance moved by cadmium to the one moved by the developer, Rf, range between 0.14 and 1.0 for soils with a mean of 0.64 . It was concluded that $\mathrm{Cd}$ was slightly mobile in $27 \%$, moderately mobile in $14 \%$, mobile in $41 \%$ and highly mobile in $18 \%$ of the soils studied (Sanchez-Cmazano et al., 1993). The $\mathrm{pH}$, sum of the exchangeable bases, exchangeable $\mathrm{Ca}$ and $\mathrm{Mg}, \mathrm{CEC}$, and clay content have a significant effect on cadmium mobility in soils (Sanchez-Cmazano et al., 1993). It wasreported that the results of complex trace metal (Cd and $\mathrm{Zn}$ ) interactions with soil components show a higher accumulation capacity for loamy soil than for sandy soil even though they have a similar CEC (Scokart et al., 1983). The addition of organic-rich wastes such as municipal sludges and industrial residues can provide enough organic matter to the soil to bind other toxic heavy metals such as $\mathrm{Cd}, \mathrm{Zn}$, and $\mathrm{Pb}$. It was suggested that heavy metals below sewage disposal sites can move downward through the soil column as soluble metal-organic complexes (MaCarthy and Perdue, 1991 , Harrison, et. al., 1999).
It was observed that metal-binding organic substances in waste water or sludge designed for land use may affect the fate of toxic metals. $\mathrm{Cd}$ adsorption in the presence of soluble organic ligands, ammonium acetate (Ac), oxalate (Ox), nitrilotriacetate (NTA), and EDTA was modified based on a competition for the metal ions between soil metal-binding sites and added soluble organic materials. In addition when the ligand bond was weaker than metal-soil such as Ox-Cd, adsorption was not affected. However, for ligands capable of strongly binding Cd (NTA and EDTA) out of competing for soil sites, adsorption was reduced due to the formation of non adsorbing complexes (Elliott and Denney 1982). Therefore it has been suggested to avoid the use of effluent containing chelating agents for irrigation (Kirkham, 1977). The importance of organic ligands on the mobility of metals in soil environments should be minimal for acidic solutions and weakly complexing ligands. (Elliott and Denney, 1982). There have been a number of studies involving the collective investigation of soil properties on the Cd sorption and mobility various regression techniques have been implemented to study what properties best describe the effect on soil Cd sorption process (Shaheen, 2009, Vega, et. al., 2010 and Cerqueira, et. al., 2011).

The aim of this research work is to study the effect of different soil characteristics on $\mathrm{Cd}$ mobility using soil thin layer chromatography (TLC) and explain the relationship between different components of soil relevant to $\mathrm{Cd}$ sorption process and to possibly understand the combining effects of these soil properties in the process. .

\section{MATERIAL AND METHODS}

Particle size distribution was determined by the pipette method after removing the cementing agents and dispersed by sodium pyrophosphate. The cation exchange capacities ( CEC) values were determined using the displacement method, using $\mathrm{NaOAc}$ buffered at $\mathrm{pH} 8.2$ with $\mathrm{Na}$ as the index cation. Additionally, $\mathrm{NH}_{4} \mathrm{OAc}$ extractable bases, namely $\mathrm{Ca}, \mathrm{Mg}, \mathrm{K}$, and $\mathrm{Na}$, were measured employing an IL Video12 atomic absorption spectrophotometer and flame emission analyses. Extractable iron and aluminum contents of the studied soils were 
determined according to Blakemore et al., (1987). The poorly crystalline, $\mathrm{Fe}_{\mathrm{o}}$ and $\mathrm{Al}_{\mathrm{o}}$ of the $\mathrm{Fe}$ and Al bearing minerals were extracted, using acid ammonium oxalate in the dark. For the total (poorly and well crystalline) oxides, hydroxides and oxyhydroxides of $\mathrm{Fe}$ and $\mathrm{Al}\left(\mathrm{Fe}_{\mathrm{d}}\right.$ and $\left.\mathrm{Al}_{\mathrm{d}}\right)$ the soils were extracted using dithionite-citrate-bicarbonate (DCB) buffer. Sodium pyrophosphate was used to extract the organically bound $\mathrm{Fe}$ and $\mathrm{Al},\left(\mathrm{Fe}_{\mathrm{p}}\right.$ and $\mathrm{Al}_{\mathrm{p}}$ ). The concentration of the inorganic poorly crystalline $\mathrm{Fe}$ fraction, $\mathrm{Fe}_{\mathrm{p}}-\mathrm{Fe}_{\mathrm{p}}$, was calculated from the difference between poorly crystalline and organically bound oxides (Evans and Wilson, 1985). Soil $\mathrm{pH}$ was measured potentiometrically in a 1:1 water to soil suspensions by using a combined $\mathrm{pH}$ electrode.

\section{Preparation of the soil plates:}

The Cadmium mobility was studied by means of soil thin layer chromatography(Soil TLC). The Soil samples were ground in a mortar and sieved through a 160-ìm nylon mesh sieve to obtain samples with a small and nearly homogeneous particle size. A soil water slurry of solid:solution ratio of $1: 2$ ( $7.5 \mathrm{~g}$ of soil and $15 \mathrm{ml}$ of distilled water) was then prepared. The plates then were coated with water slurry of the soil $(0.5 \mathrm{~mm}$ thickness) over each of the $20 \times 5 \mathrm{~cm}$ plates with aid of an ordinary
TLC applicator. The selected plates, which have an even soil thickness distribution, were then air dried at room temperature and relative humidity of $70 \%$ in a desiccating chamber.

\section{Soil TLC procedures:}

The plates were marked with two horizontal lines at different distances from the base ( 3 and 13 $\mathrm{cm}$ ) so that the standard development distance of $10 \mathrm{~cm}$ was used in all the plates. A 5 il aliquot of cadmium nitrate solution $\left(\mathrm{Cd}\left(\mathrm{NO}_{3}\right)_{2} 0.1 \mathrm{M}\right)$ was applied as spot on the base line of triplicate TLC plates in a single application with the micro pipette. The drops were placed at a distance of $3 \mathrm{~cm}$ from the bottom of the plates.

The loaded plates were then developed by ascending chromatographic tank containing distilled water as solvent. The development was done for 1-3 hour depending on soil sample textures. Then, the plates were washed for $13 \mathrm{~cm}$ from the baseline and allowed to dry at room temperature. The dried plates were sprayed with $0.05 \%$ dithizone in $\mathrm{CCl}_{4}$ in order to detect $\mathrm{Cd}$ as orange spots of $\mathrm{Cd}$-dithizone.

Cadmium mobility was measured visually as the frontal $R f(\mathrm{~cm})$ value (mobility) using the following relationship:

Table. 1: Soil Properties.

\begin{tabular}{|c|c|c|c|c|c|c|c|c|c|c|}
\hline & & sand & silt & clay & $\mathrm{pH}$ & Cation & Exc & angeab & catio & \\
\hline Soi & & & & & & exchange & $\mathrm{Ca}^{2+}$ & $\mathbf{M g}^{2+}$ & $\mathrm{Na}^{+}$ & $\mathbf{K}^{+}$ \\
\hline Cla & ssification & & & & & pacity (CEC & & cmol & & \\
\hline 1 & Typic Torrifluvents & 22 & 51 & 27 & 8.4 & 23.7 & 10.0 & 1.8 & 8.0 & 1.9 \\
\hline 2 & Typic Natrargids & 64 & 21 & 15 & 8.2 & 10.9 & 8.0 & 1.4 & 0.9 & 1.5 \\
\hline 3 & Typic Torrifluvents & 60 & 24 & 16 & 8.4 & 10.6 & 6.8 & 2.0 & 1.4 & 0.7 \\
\hline 4 & Vertic Haplustolls & 18 & 51 & 31 & 8.2 & 25.2 & 14.6 & 3.4 & 6.0 & 1.2 \\
\hline 5 & Typic Calciorthids & 84 & 7 & 9 & 8.8 & 4.1 & 2.2 & 0.6 & 0.9 & 0.3 \\
\hline 6 & Ustollic amborthids & 38 & 44 & 18 & 6.3 & 16.0 & 2.8 & 2.2 & 1.4 & 1.0 \\
\hline 7 & Typic Hydrudands & 84 & 13 & 3 & 4.9 & 99.0 & 0.2 & 0.5 & 1.5 & 0.3 \\
\hline 8 & Entic Hapludands & 20 & 64 & 16 & 6.9 & 33.7 & 11.6 & 2.4 & 0.3 & 2.6 \\
\hline 9 & Typic Hydrudands & 34 & 53 & 13 & 7.0 & 62.5 & 4.2 & 1.0 & 0.3 & 1.3 \\
\hline 10 & Typic Ustivitrands & 73 & 20 & 7 & 7.4 & 18.6 & 5.5 & 3.3 & 0.6 & 0.5 \\
\hline 11 & Typic Ustivitrands & 94 & 5 & 1 & 7.8 & 6.3 & 1.0 & 1.7 & 0.7 & 0.2 \\
\hline 12 & Typic Hydrudands & 70 & 27 & 3 & 6.9 & 5.8 & 1.5 & 0.5 & 0.1 & 0.1 \\
\hline 13 & Typic Hydrudands & 55 & 39 & 6 & 4.9 & 21.3 & 2.5 & 1.4 & 2.3 & 0.2 \\
\hline 14 & Typic Haplocryands & 34 & 54 & 12 & 6.1 & 22.3 & 5.3 & 0.4 & 0.1 & 1.2 \\
\hline
\end{tabular}




$$
\mathrm{Rf}=\frac{F m}{F d}
$$

Where $\mathrm{Fm}$ is frontal distance moved by the metal and $\mathrm{Fd}$ is the one moved by the developer solution.

\section{RESULS AND DISCUTION}

\section{Soil Properties:}

The fourteen soils investigated in this research are characterized by the parameters given in Tables 1 and 2. The soils range in particle size distribution and texture from sand to silty clay.

They exhibited a range of $\mathrm{pH}$ values from strongly acidic ( $\mathrm{pH}$ of 4.9$)$ to strongly alkaline $(\mathrm{pH}$ of 8.8), and a wide range of CEC from very low of 4.1 $\mathrm{cmol} / \mathrm{kg}$ to very high of $99.0 \mathrm{cmol} / \mathrm{kg}$.

\section{Mobility in relation to soil properties:}

Table 3, shows the cadmium mobility Rf values which were derived from the chromatograph obtained for the different soils, which are considered to be a measure of mobility in thin layer chromatography (TLC). The frontal $\mathrm{Rf}$ values was estimated using the following relationship:

$$
\mathrm{Rf}=\frac{F m}{F d}
$$

Where $F_{m}$ is frontal distance moved by the metal and $F_{d}$ is the one moved by the developers solution.

The Rf values obtained ranged between 0.25 and $0.95(\mathrm{~cm})$. The results suggest that $\mathrm{Cd}$ mobility in these soils was highly variable. Because the soil TLC technique has only recently begun to be used for estimating metal mobility such as $\mathrm{Cd}$ in soils, and also with the lack of sufficient published data in this field, there is no mobility classification according to Rf except the one proposed by Helling and Turner (1968) for pesticide mobility in soils. The cadmium mobility classifications in the soils studied according to Hellingand Turner (1968) are shown in Table 4. Based on this classification cadmium was slightly mobile in $64 \%$, moderately mobile in 29 $\%$ and very mobile in $7 \%$ of the soils investigated. The distance moved by cadmium (Fig. 1) was the highest in the soil with a high sand percentage (soil 16) and the lowest for those of high silt and/or clay percentages (soil 1). In general soils with high percentages of sand (soil 10,12, and 15) fall in the moderately mobile class.

There was a significant correlation at the 0.05 probability level between $\mathrm{Rf}$ values and sand percentage. There were also a significant negative

\begin{tabular}{|c|c|c|c|c|c|c|c|c|}
\hline \multirow[t]{2}{*}{$\begin{array}{l}\text { Soil Classification } \\
\text { No. }\end{array}$} & \multirow[b]{2}{*}{ O.C } & \multicolumn{2}{|c|}{$\begin{array}{l}\text { Oxalate } \\
\text { extractable }\end{array}$} & \multicolumn{2}{|c|}{$\begin{array}{c}\text { Na-yrophosphate } \\
\text { extractable }\end{array}$} & \multicolumn{3}{|c|}{ DCB extractable } \\
\hline & & $\mathrm{Fe}_{\mathrm{o}}$ & $\mathrm{Al}_{\text {。 }}$ & $\mathrm{Fe}_{\mathrm{p}}$ & $\begin{array}{c}A I_{p} \\
g k^{-}\end{array}$ & $\mathrm{Fe}_{\mathrm{d}}$ & $\mathrm{Al}_{\mathrm{d}}$ & $\mathrm{Fe}_{\mathrm{o}}-\mathrm{Fe}_{\mathrm{p}}$ \\
\hline 1Typic Torrifluvents & 3.6 & 1.7 & 3.4 & 0.1 & 0.4 & 2.9 & 3.0 & 1.6 \\
\hline 2Typic Natrargids & 2.8 & 3.7 & 3.2 & 0.1 & 3.7 & 2.7 & 3.1 & 3.6 \\
\hline 3Typic Torrifluvents & 2.1 & 2.8 & 2.2 & 0.1 & 2.1 & 3.8 & 2.3 & 2.8 \\
\hline 4Vertic Haplustolls & 4.4 & 2.3 & 3.6 & 0.2 & 3.0 & 2.8 & 2.2 & 2.1 \\
\hline 5Typic Calciorthids & 7.8 & 4.4 & 1.5 & 0.1 & 1.2 & 5.4 & 2.9 & 4.4 \\
\hline 6Ustollic Camborthids & 7.1 & 8.8 & 8.4 & 1.0 & 2.0 & 51.0 & 8.0 & 7.8 \\
\hline 7Typic Hydrudands & 20.1 & 10.1 & 81.6 & 3.0 & 31.0 & 16.0 & 36.0 & 7.1 \\
\hline 8Entic Hapludands & 28.0 & 21.1 & 8.5 & 1.0 & 2.3 & 34.9 & 6.2 & 20.1 \\
\hline 9Typic Hydrudands & 29.0 & 31.0 & 17.0 & 3.0 & 6.0 & 33.0 & 8.4 & 28.0 \\
\hline 10Typic Ustivitrands & 11.6 & 29.7 & 5.2 & 0.8 & 2.3 & 27.0 & 3.1 & 29.0 \\
\hline 11Typic Ustivitrands & 11.1 & 12.2 & 5.7 & 0.6 & 3.3 & 14.0 & 5.5 & 11.6 \\
\hline 12Typic Hydrudands & 7.1 & 13.1 & 8.6 & 2.0 & 1.0 & 11.0 & 3.0 & 11.1 \\
\hline 13Typic Hydrudands & 11.0 & 15.1 & 13.0 & 8.0 & 9.0 & 14.0 & 9.0 & 7.1 \\
\hline 14Typic Haplocryands & 22.9 & 11.9 & 20.2 & 0.9 & 4.2 & 34.3 & 8.7 & 11.0 \\
\hline
\end{tabular}

Table. 2: Soil Properties. 
correlation $(p<0.05)$ between silt \%,clay \%, exchangeable ( $\mathrm{Ca}$ and $\mathrm{K}$ ) soil contents and the $\mathrm{Rf}$ values. The other soil properties including $\mathrm{pH}, \mathrm{CEC}$, and organic carbon content, where not significant at $(p<0.05)$.

The variability in the cadmium mobility in the soils is mostly accounted for by sand $(r=0.63)$, followed by silt \%; $(r=-0.59)$; the exchangeable $\mathrm{Ca}(r$ $=-0.55)$; clay $\%(r=-0.55)$ and the exchangeable $\mathrm{K}$ $(r=-0.49)$. The Rf values below 0.35 were generally measured for soils with relatively a higher percentage of clay and silt than the rest of the soils studied. Both clay and silt percentages showed a significant correlation with measured Rf values. The Soils that have $\mathrm{Rf}>0.35$ or soils classified as moderately mobile with respect to cadmium movements, shared either a higher sand \% (soil 12, and 15), and /or lower $\mathrm{pH}$ values as the case of soil 19. Only one soil, soil 16, classified as very mobile with regards to cadmium movements has the highest amount of sand $(94 \%)$ and the lowest clay content of (1\%) .The $\mathrm{Rf}$ values of the soils were plotted as a function of sand \% in soils and shown in (Fig. 2). The plots show that the higher the sand $\%$, the higher will be the mobility of $\mathrm{Cd}$ in soils. The divalent cation, $\mathrm{Ca}^{2+}$, was negatively correlated with $\mathrm{Rf}(\mathrm{p}<0.05)$, which could be a result of competition between $\mathrm{Cd}^{2+}$ and exchangeable $\mathrm{Ca}^{2+}$ for the sorbing sites. McBride et al, (1981), found the cadmium retention capacity of soils to be dependent significantly on the exchangeable $\mathrm{Ca}^{2+}$ content of soils. It was found the competition of cadmium with exchangeable cations to decrease in the following order $\mathrm{Al}<\mathrm{Ca}<\mathrm{K}<\mathrm{Na}$.

Table. 3: Rf Values for the Mobility of Cadmium in the Soil

\begin{tabular}{|c|c|c|c|c|c|c|c|c|}
\hline \multirow{2}{*}{$\begin{array}{l}\text { Soil. } \\
\text { No }\end{array}$} & \multicolumn{3}{|c|}{ Replications } & \multicolumn{3}{|c|}{ Replications } & \multirow[t]{2}{*}{ Mean } & \multirow[t]{2}{*}{ S.D } \\
\hline & ${ }^{\mathrm{a}} \mathbf{d} 1$ & ${ }^{\mathrm{a}} \mathrm{d} 2$ & ${ }^{\mathrm{a}} \mathrm{d} 3$ & 1Rf & $2 \mathrm{Rf}$ & $3 \mathrm{Rf}$ & & \\
\hline 1 & 2.60 & 2.50 & 2.30 & 0.26 & 0.25 & 0.23 & 0.25 & 0.01 \\
\hline 2 & 2.40 & 2.30 & 3.10 & 0.24 & 0.23 & 0.31 & 0.26 & 0.04 \\
\hline 4 & 3.10 & 3.00 & 2.50 & 0.31 & 0.30 & 0.25 & 0.29 & 0.03 \\
\hline 6 & 2.60 & 2.30 & 2.90 & 0.26 & 0.23 & 0.29 & 0.26 & 0.02 \\
\hline 10 & 5.30 & 4.90 & 4.90 & 0.53 & 0.49 & 0.49 & 0.50 & 0.02 \\
\hline 11 & 4.30 & 4.50 & 3.80 & 0.43 & 0.45 & 0.38 & 0.42 & 0.03 \\
\hline 12 & 4.70 & 4.30 & 4.90 & 0.47 & 0.43 & 0.49 & 0.46 & 0.02 \\
\hline 13 & 2.60 & 2.60 & 2.60 & 0.26 & 0.26 & 0.26 & 0.26 & 0.00 \\
\hline 14 & 2.60 & 3.10 & 3.60 & 0.26 & 0.31 & 0.36 & 0.31 & 0.04 \\
\hline 15 & 4.40 & 3.50 & 4.10 & 0.44 & 0.35 & 0.41 & 0.40 & 0.04 \\
\hline 16 & 9.50 & 9.90 & 9.00 & 0.95 & 0.99 & 0.90 & 0.95 & 0.04 \\
\hline 17 & 2.00 & 2.90 & 3.90 & 0.20 & 0.29 & 0.39 & 0.29 & 0.08 \\
\hline 18 & 3.50 & 2.60 & 3.50 & 0.35 & 0.26 & 0.35 & 0.32 & 0.04 \\
\hline 19 & 4.20 & 3.80 & 3.90 & 0.42 & 0.38 & 0.39 & 0.40 & 0.02 \\
\hline
\end{tabular}

aFrontal distance in $(\mathrm{cm})$ traveled by $\mathrm{Cd}^{2+}$

Table. 4: Cadmium Cobility in Soils

\begin{tabular}{ccccc}
\hline${ }^{a}$ Class & Rf & Mobility & Soil No. & Soil (\%) \\
\hline 2 & $0.10-.34$ & Slightly mobile & $1,2,4,6,11,13,14,17,18$ & 64 \\
3 & $0.35-0.64$ & Moderately mobile & $10,12,15,19$ & 29 \\
4 & $0.65-0.89$ & Mobile & 0 & 0 \\
5 & $0.90-1.0$ & Very mobile & 16 & 7 \\
\hline
\end{tabular}

${ }^{\mathrm{a} C l a s s i f i c a t i o n ~ a c c o r d i n g ~ t o ~ H e l l i n g ~ a n d ~ T u r n e r ~(1968) . ~}$ 
The competition of $\mathrm{Cd}$ with these cations was also found in this study to decrease in the order of $\mathrm{Ca}<$ $\mathrm{K}<\mathrm{Na}<\mathrm{Mg}$ which is consistence with the variation of the correlation coefficients of Rf with the amounts of these elements in the soils (Matos et al., 2001, Benaissa and Benguella, 2004). The correlation between $\mathrm{Rf}$ values and soil $\mathrm{pH}$ was insignificant and negative which indicates at least that increasing the soil $\mathrm{pH}$ will decease $\mathrm{Rf}$ and cadmium mobility in soils. Soil organic carbon content and CEC showed a negative and insignificant correlation with $\mathrm{Rf}$, which suggests that these factors can be important in limiting cadmium mobility to a lesser degree than divalent cations specially $\mathrm{Ca}^{2+}$ or clay and silt contents. The correlation between $\mathrm{Rf}$ values and iron and aluminum was insignificant. The contents of iron and aluminum oxides in the soils showed that they played an insignificant role in cadmium mobility.

\section{Assessment of groundwater contamination potential}

The mobility of $\mathrm{Cd}$ also was evaluated by means of the cadmium retardation factor, Rcd.

The retardation factor $\mathrm{Rcd}$, represents the ratios of the average linear velocity of groundwater (ý) to that of dissolved Cd (vs).

$$
\mathrm{R}_{\mathrm{R}} \mathbf{1}+\frac{p b}{n} * k d=\frac{\mathrm{v})}{\mathrm{v}}
$$

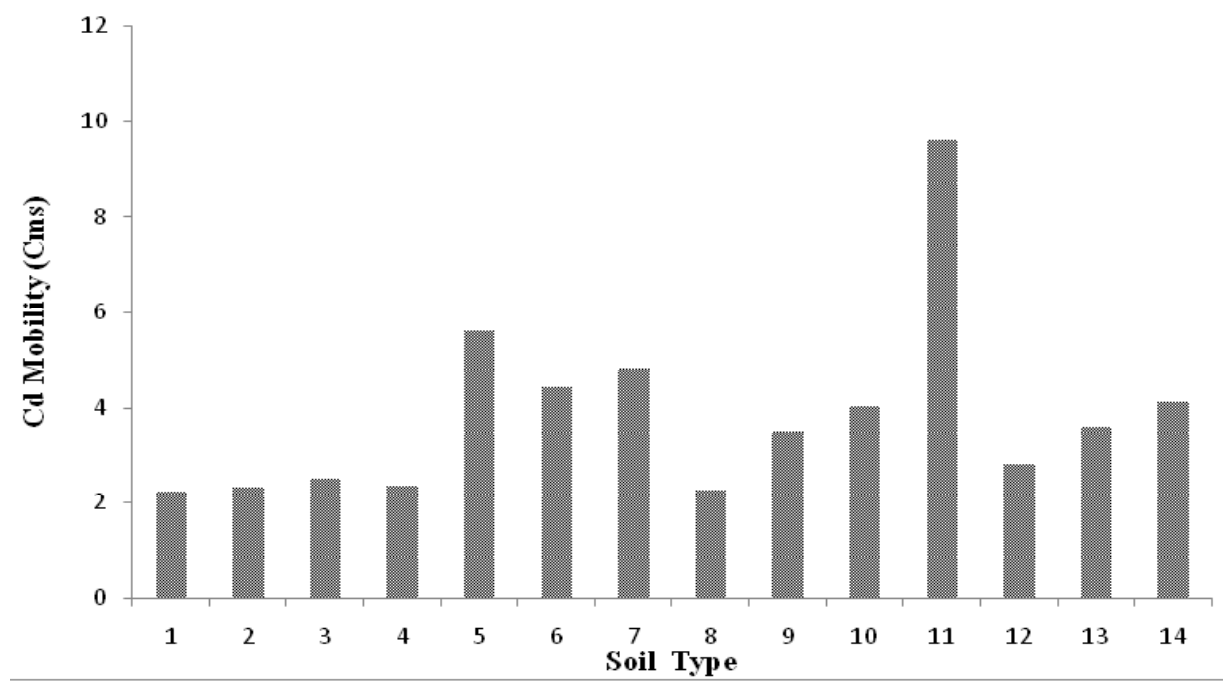

Fig. 1: Distance $(\mathrm{cm})$ moved by cadmium over a $10 \mathrm{~cm}$ soil TLC

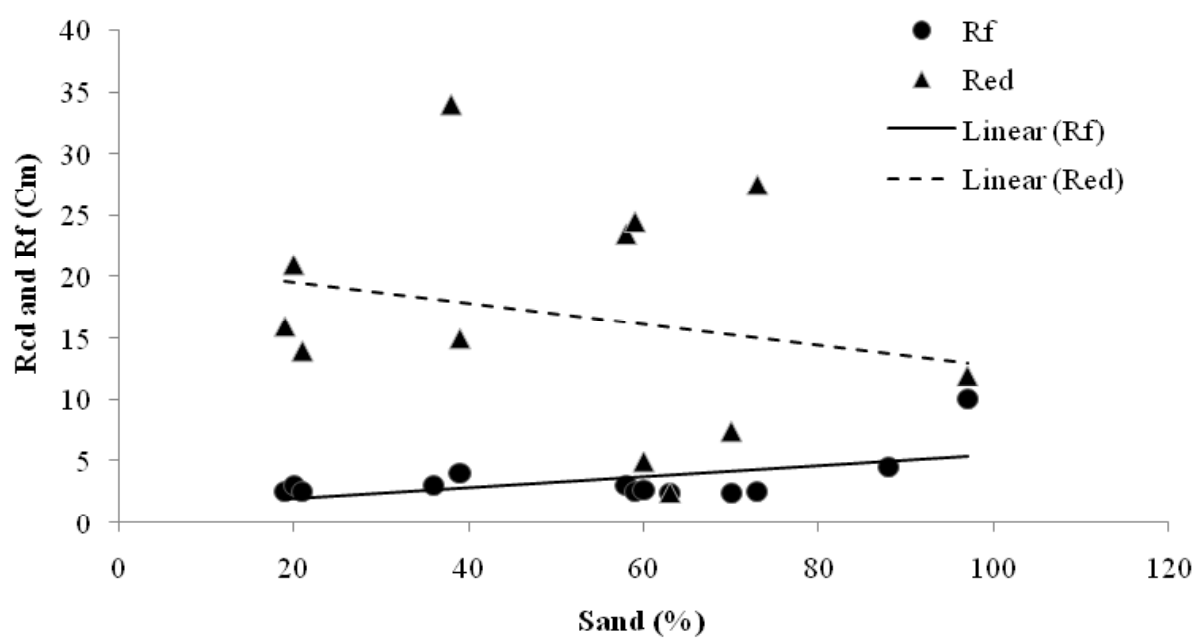

Fig. 2: Rf values plotted against Sand \% for 14 types of soils under study 
Where pb the soil bulk density, $\mathrm{n}$ is the soil porosity, and the kd is the empirical distribution coefficient for sorbing $\mathrm{Cd}$ which is the solid phase concentration of $\mathrm{Cd}$ divided by the dissolved $\mathrm{Cd}$ concentration. Also, the Rcd value can be calculated from, fw, which is the form of a compound in the water solution in a volume containing both solid and water as follows

$$
\mathrm{fW}=\frac{1}{1+\left(\frac{\mathrm{Ms}}{\mathrm{VM}}\right) \frac{1}{* K d}}
$$

Where Ms is mass of soil used $(0.5 \mathrm{~g})$, and $\mathrm{VM}$ is the volume of the solution used $(25 \mathrm{ml})$. The $\mathrm{Rcd}$ is equal to $1 / \mathrm{fw}$.
The kd factor is usually expressed in units of $\mathrm{ml} / \mathrm{g}$, derived as follows:

$$
\mathrm{Kd}=\frac{\mathrm{mgCd} / \mathrm{gSoil}}{\mathrm{mgCd} / \mathrm{mlsolution}}=\frac{\mathrm{ml}}{\mathrm{g}}
$$

The $\mathrm{Kd}$ values for soils studied were obtained by mean of batch adsorption experiment at fixed total Cd load of $12.8 \mathrm{ppm}$ on order to calculate the retardation factor values of $\mathrm{Cd}(\mathrm{Rcd})$. The $\mathrm{Rcd}$ values of the soils studied at fixed total $\mathrm{Cd}$ load of $12.8 \mathrm{ppm}$ and at their natural $\mathrm{pH}$ varied from 2.9 to 33.42 . The Rcd values for the soils studied were found to be increasing with increasing $\mathrm{pH}$ and also to differ from soil to soil. In order to determine

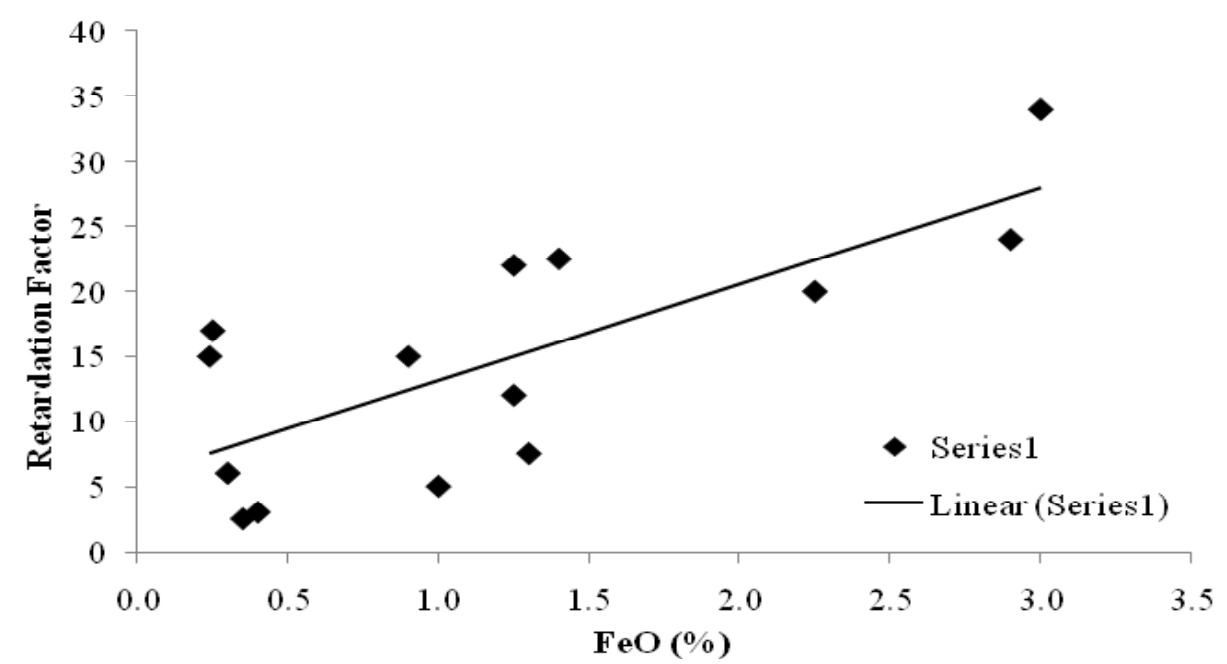

Fig. 3: $\mathrm{FeO}(\%)$ plotted against the log of retardation factor of 14 soils studied using TLC

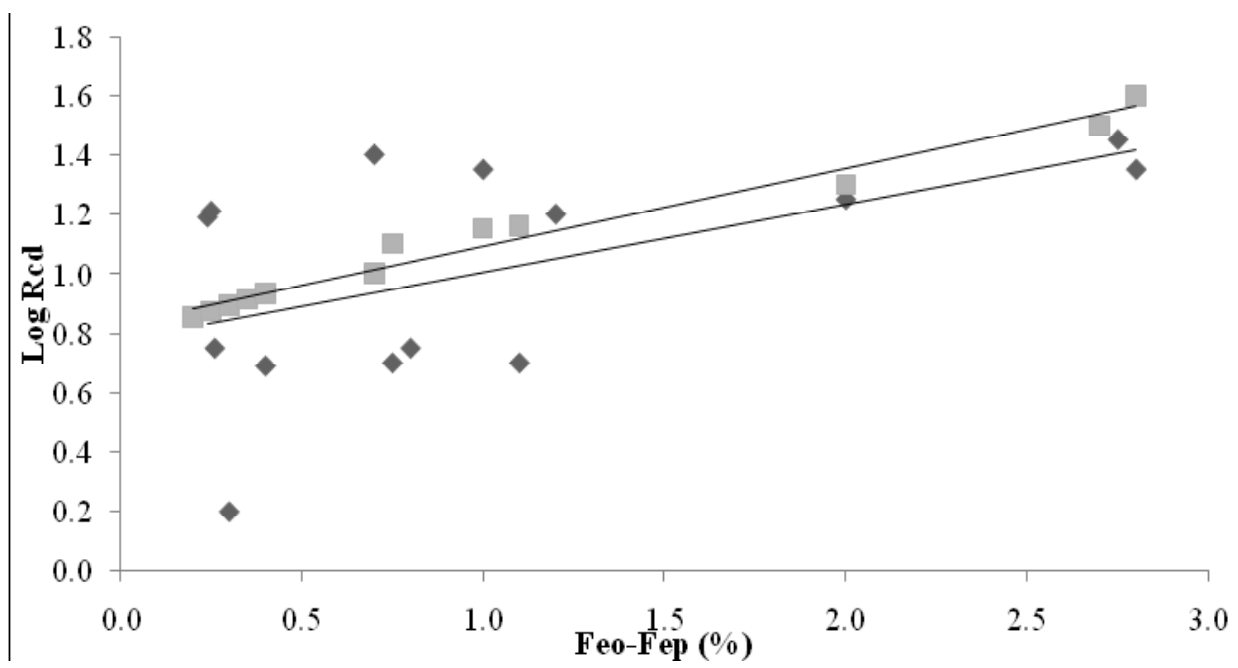

Fig. 4: FeO-FeP (\%) plotted against the log of retardation factor of 14 soils studied using TLC 
the influence of soil properties on the cadmium movement, the simple correlation coefficient between the cadmium retardation factor Rcd and soil properties was conducted. There is significant correlations between Rcd values and Feo, Fe0-Fep, and silt $(p<0.01)$; and Fed at $(p<0.05)$; Fep and the exchangeable $\mathrm{Mg}^{2+}$ at $(\mathrm{p}<0.1)$. Also there is a significant, though negative correlation between Rcd and sand $\%$ at $(p<0.05)$. The Rcd values increase with increasing amounts of the iron oxide fractions (Feo, Fep, and Fed); silt\% and exchangeable $\mathrm{Mg}^{2+}$ in the soils (Figure 3 and 4).

The quantities of extractable aluminum oxide fractions in the soils show a negative but not significant correlation with measured Rcd. Soils with a high percentage of sand seem to favor cadmium mobility over retention or low Rcd values and high Rf values (Fig.2). Both Rcd and Rf factors were significantly correlated $(p<0.05)$ with sand and silt percentages. Rcd increases rapidly with $\mathrm{pH}$ and is consistently somewhat greater for soils with higher iron contents.. The Rcd increased with increasing quantities of either poorly crystalline inorganic or organically bound irons in soils.

\section{CONCLUTION}

The $\mathrm{Rf}$ values obtained ranged from 0.25 to 0.95 which suggested that $\mathrm{Cd}$ mobility in these soils is highly variable. Cadmium mobility was found to be slightly mobile in $64 \%$, moderately mobile in $29 \%$ and very mobile in $7 \%$ of the soils investigated. The variability in the cadmium mobility in the soils is mostly accounted for by the sand $\%(r=0.63)$, followed by the silt \%; $(r=-0.59)$; the exchangeable $\mathrm{Ca}(r=-0.55)$; the clay $\%(r=-0.55)$ and the exchangeable $K(r=-0.49)$. Rcd values increased with increasing amounts of the iron oxide fractions (Feo, Fep, and Fed); silt \% and exchangeable $\mathrm{Mg}^{2+}$ in the soils. Finally, both Rcd and Rf factors showed Cd mobility to be higher in those soils with a high percentage of sand.

\section{ACKNOWLEDGMENT}

This project was supported by King Saud University, Deanship of Scientific Research, College of Food \& Agriculture Sciences, Research Center.
1. Roth, E., Mancier, V., Fabre, B. Adsorption of cadmium on different granulometric soil fractions: Influence of organic matter and temperature, Geoderma, 189-190, 133-143. (2012).

2. Moradi, A., Abbaspour, K.C., Afyuni, M. Modelling field-scale cadmium transport below the root zone of a sewage sludge amended soil in an arid region in Central Iran. Journal of ContaminantHydrology 79, 187-206 (2005).

3. Keller, A., Abbaspour, K.C., Schulin, R. Assessment of uncertainty and risk in modeling regional heavy-metal accumulation in agricultural soils. Journal of Environmental Quality 31, 175-187.(2002)

4. Van der Grift, B., Griffioen, J. Modelling assessment of regional groundwater contamination due to historic smelter emissions of heavy metals. Journal of Contaminant Hydrology 96, 48-68 (2008).

5. Streck, T., Richter, J. Heavy metal displacement in a sandy soil at the fieldscale: I. Measurements and parameterization of sorption. Journal ofEnvironmental Quality 26, 49-56.(1997).

6. Deurer, M., Bottcher, J. Evaluation of models to upscale the small scalevariability of $\mathrm{Cd}$ sorption in a case study. Geoderma 137, 269-278. (2007).

7. Krishnamurti, G., Naidu, R. Solid-solution equilibria of cadmium in soils. Geoderma 113, 17-30. (2003).

8. Calace, N., Deriu, D., Petronio, B.M., Pietroletti, M. Adsorption isotherms and breakthrough curves to study how humic acids influence heavy metal-soilinteractions. Water Air Soil Pollut. 204, 373-383. (2009).

9. Vega, F.A., Andrade, M.L. CoveloE.F. Influence of soil properties on the sorption and retention of cadmium, copper and lead, separately and together, by 20 soil horizons: Comparison of linear regression and tree regression analyses. Journal of Hazardous 
Materials, 174, 522-533. (2010).

10. Shaheen, S,M. Sorption and lability of cadmium and lead in different soils from Egypt and Greece. Geoderma, 153, 61-68.(2009).

11. Segura, R.,Arancibia, V.,Zú̃niga, M.C.,Pastén, P.,2006, Distribution of copper, zinc, lead and cadmium concentrations in stream sediments from the Mapocho River in Santiago, Chile, J. Geochem. Explor. 91, 71-80.(2006).

12. Scokart, P. O., Meeus-Verdinne, K. \& De Borger, R. Mobility of heavy metals in polluted soils near zinc smelters. Water Air Soil Pollut., 20, 451-63. (1983).

13. Lindsay,W.L. Chemical equilibrium in soils. John Wiley, New York. (1979).

14. Berggren, D. Speciation and mobilization of aluminum and cadmium in Podozols and Cambisols of South Sweden. Water, Air , and Soil Pollute, 62: 125-126. (1992).

15. Fuller,W.H. Movement of selected metals. Asbestos and cyanide in soil: Application to waste disposal problem. EPA-600/2-77020. Solid and Hazardous waste Research Cincinnati, OH. (1977).

16. Sanchez-Camazano. M Sanchez-Martin, M. J. 1993.Adsorption and mobility of cadmium in natural, uncultivated soils. J. Environ. Qual. 22: 737-742. (1991)

17. MaCarthy P, Perdue E.M. Complexation of metal ions by humic substances: fundamental considerations. In: Bolt FH, DeBoot MF, Hayes MHB, McBride MB (eds), Interactions at the Soil Colloid-Soil Solution Interface, pp.469489. Kluwer Academic Publishers, Dordrecht. (1991).

18. Harrison, E.Z., McBride, M.B. and Bouldin, D.R. Land application of sewage sludges: an appraisal of the US regulations. Int. J. Environment and Pollution, 11, 1-36.
(1999).

19. Elliott, A. H., and Denney, C.M. Soil adsorbtion of cadmium from solutions containing organic ligands. Journal of Environmental Quality, 11, 658-662. (1982).

20. Kirkham, M.B. Elemental composition of sludge-fertilized chrysanthemums. Journal of the American Society for Horticultural Science 102: 352-354. (1977).

21. Cerqueira, B.,Covelo, E. F., Andrade, L., Vega, F. A. The influence of soil properties on the individual and competitive sorption and desorption of $\mathrm{Cu}$ and $\mathrm{Cd}$. Geoderma, 162, 20-26. (2011).

22. Blakemore, S.C., P.S. Searle, and B.K. Daly. Methods for chemical analysis of soils. N.Z. Bur, Sci. Rp.80. N.Z. Soil Bureau, Sower Hutt, N.Z.(1987).

23. Evans, L. J. and W.G. Wilson. Extractable Fe, $\mathrm{Al}$, Si and $\mathrm{C}$ in B horizons of Podozolic and Brunisolic soils from Ontario. Can. J. of Soil Sci. 65: 489-496. (1985).

24. Helling, C. S., and Tumer, B.C. Pesticide mobility: Determination by soil thin-layer chromatography. Science, 162: 562-563. (1968).

25. Matos A.T., M.P.F. Fontes, L.M. da Costa and M.A. Martinez. Mobility of heavy metals as related to soil chemical and mineralogical characteristics of Brazilian soils. Environmental Pollution. 111: 429-435. (2001).

26. Benaissa, H., and Benguella, B. Effect of anions and cations on cadmium sorption kinetics from aqueous solutions by chitin: experimental studies and modeling. Environmental Pollution, 130, 157-163. (2004). 